\title{
Rationality of creating mechanisms of state regulation of investment activities in the context of environmental processes
}

\author{
Madina Abdulkadyrova ${ }^{1,{ }^{*}}$, Zarema Sarakayeva $^{1}$, Aset Tazbiyeva ${ }^{1}$, and Zaynap Tazbiyeva ${ }^{1}$ \\ ${ }^{1}$ Grozny State Oil Technical University named after Academician MD, 100, Kh.A. Isaeva str., \\ Millionshchikov, Chechen Republic, Grozny, Russia
}

\begin{abstract}
The paper discloses the conceptual and theoretical foundations and approaches to the formation of state mechanisms for regulating the development and implementation of eco-economically efficient investment projects. The mechanisms of state regulation of investment activity, like similar mechanisms in other spheres of activity, are guided by a quite definite result, which can be called target. This result is the effects obtained in the form of the impact of the processes of economic activity of an industrial enterprise on the environment after the implementation of the investment project.The main mechanism for the implementation of regulatory and legal support is economic one based on the development of state forecasts of the socio-economic development of the country, its individual regions and their ecological state. In our opinion, the economic mechanism should also be based on forecasts of investment activities carried out from various sources and various industries, regions, a forecast assessment of the investment attractiveness of the national economy in general, industries, regions.
\end{abstract}

\section{Introduction}

The mechanisms of state regulation of investment activity, like similar mechanisms in other spheres of activity, are guided by a quite definite result, which can be called target. This result is the effects obtained in the form of the impact of the processes of economic activity of an industrial enterprise on the environment after the implementation of the investment project.

The main mechanism for the implementation of regulatory and legal support is economic one based on the development of state forecasts of the socio-economic development of the country, its individual regions and their ecological state. In our opinion, the economic mechanism should also be based on forecasts of investment activities carried out from various sources and various industries, regions, a forecast assessment of the investment attractiveness of the national economy in general, industries, regions, in particular.

*Corresponding author: salima@list.ru 
Nowadays, the economic mechanisms for regulating investment activities include the provision of tax and other benefits when introducing the best existing eco-efficient technologies that allow the use of production and consumption waste as secondary resources, reduce the load on the territory (dumping), support entrepreneurial activities in the field of environmental protection, development of environmental innovations, including environmental insurance $[1,2]$.

It is important to note that investment activities carried out for the purpose of a balanced, sustainable use of natural resources, environmental protection, introduction of new environmentally friendly safe products and technologies are supported by state mechanisms for regulating environmental investment activities, which mainly include tax incentives.

The theoretical and methodological basis of the study was the works on the problems of sustainable development, rational nature management, formation of investment projects and assessment of their effectiveness, creation of rational mechanisms of state control and regulation of economic and environmental activities of such domestic and foreign scientists as N.V. Pakhomov, N. D. Sorokin, S.A. Rafikov, A.I. Chistobaev, R. Welford, L. Vicke, G. Winter, K. Richter, D. Forrester.

\section{Materials and Methods}

The information base of the study was made up of materials from the State Strategy for Sustainable Development of the Russian Federation, Industrial Policy of the Russian Federation, Environmental Doctrine of the Russian Federation, investment policy of the Russian Federation and its regions, the International Commission on Environment and Development, State Reports on Industrial Development, on the state of the environment, as well as statistical data on the state of industrial development and indicators of the ecological state of the natural environment in the regions of the Russian Federation.

The study used the methods of expert assessments, scenario building, system analysis, and calculation of economic efficiency.

\section{Results and Discussion}

In order to prevent the negative impact on the environment of production and economic activities, standards for permissible environmental impact are established for industrial enterprises as legal entities, which, in our opinion, are the constraints that allow an investment project to be classified as eco-efficient if the standards are observed or the projected values of the volumes of environmental pollution are below the standards. Such standards include the following: waste generation, production and consumption, limits on their placement, standards for permissible emissions and discharges of substances, microorganisms; standards for the permissible withdrawal of components of the natural environment, permissible anthropogenic load on the territory [3].

As one of the elements of ensuring the environmental safety of investment projects, environmental certification is divided into two types - mandatory and voluntary. A fundamentally important method of the mechanism of state regulation of investment activities is the assessment of the impact on the environment, which is necessary and is carried out at the stage of design of investments in production and economic facilities. In addition, an assessment of the environmental impact and its expected direct or indirect impact on the environment should be carried out when developing all options for investments, at all stages of creating a new economic entity - pre-project, including preinvestment, technical and detailed design. 
However, the state mechanism for regulating investment activities based on the use of the law under consideration, for example, contains requirements for environmental protection processes during the production and operation of cars and other vehicles, but does not reflect the requirements for waste disposal during the operation of vehicles, wornout car tires.

State control, being an integral part and the basis for state regulation, is carried out according to the analyzed legislation in the following forms - state, municipal, industrial and public $[8,9]$. However, according to the legislation, as before, there are no specially authorized government bodies that would carry out state environmental control of investment projects. The tasks of such control are performed by executive authorities at the federal and regional levels. Responsibility for violation of the law lies in the fact that industrial enterprises are obliged by law to fully compensate for damage to the environment, including from investment projects that have a positive conclusion of the state ecological expertise.

Thus, damage to the environment should be compensated according to the approved methods in accordance with the procedure established by the regulatory mechanisms for the created rates, and in the absence of methods, by payment, based on actual costs, taking into account the losses incurred and lost profits. Particular attention should be paid to the longterm nature of the action of the organizational and administrative mechanism of state regulation, since claims for compensation for damage caused to environmental components as a result of violation of legislation can be brought within twenty years. The suspension or termination of the activity of an industrial enterprise, carried out in violation of environmental legislation, can be carried out by a court or an arbitration court, and not by supervisory authorities, as it was before the adoption in early 2002 of a new law regulating any activities, including investment ones, in the field of environmental protection [4].

In our opinion, the new system of state legal regulation more adequately reflects the development trends of the national economy of Russia, its industries and territories, and helps to attract investments in eco-efficient projects.

So, for example, investment activity in the existing transitive conditions includes the processes of investing in fixed assets of industrial enterprises that form the whole manufacturing industry and individual economic entities in these industries, differing in forms of ownership - state, foreign, private [5]. In addition, investments in environmental protection differ in terms of their reproductive structure: expenses for capital repairs of environmental protection equipment, technical re-equipment and reconstruction of existing industrial enterprises in order to introduce eco-efficient products and technologies; expansion of existing enterprises producing environmentally friendly, low-waste products; construction of new enterprises, including those using secondary raw materials (waste) as material resources; construction and assembly work for the installation of new equipment, technological lines, areas for the production of environmentally friendly products; the costs of maintaining existing capacities at enterprises that meet the requirements of environmental friendliness, preservation of the quality of the components of the natural environment [6].

So, according to the data presented in Table 1, in the North Caucasus Federal District in 2019 , investments in fixed assets aimed at environmental protection and rational use of natural resources amounted to 2,139.5 million rubles. Moreover, the bulk of these funds fell on the protection and rational use of water resources in the Chechen Republic and the Stavropol Territory. Protection and rational land use accounted for 850.5 million rubles. Most of the funds were spent by the Republic of North Ossetia-Alania and the Chechen Republic. 
Table 1. Investments in fixed assets aimed at environmental protection and rational use of natural resources in 2019 (in actual prices; million rubles).

\begin{tabular}{|l|c|c|c|c|c|}
\hline & & \multicolumn{4}{|c|}{ of them on } \\
\cline { 2 - 6 } & Total & $\begin{array}{c}\text { protection } \\
\text { and rational } \\
\text { use of water } \\
\text { resources }\end{array}$ & $\begin{array}{c}\text { air } \\
\text { protection }\end{array}$ & $\begin{array}{c}\text { protection of the } \\
\text { environment from } \\
\text { protection } \\
\text { the harmful effects } \\
\text { use of land } \\
\text { of production and } \\
\text { consumption } \\
\text { waste }\end{array}$ \\
\hline Russian Federation & $\mathbf{1 5 7 6 5 1}$ & $\mathbf{6 2 7 5 0}$ & $\mathbf{6 5 4 7 5}$ & $\mathbf{1 0 0 1 0}$ & $\mathbf{1 5 2 2 1}$ \\
\hline $\begin{array}{l}\text { North Caucasian } \\
\text { Federal District }\end{array}$ & $\mathbf{2 1 3 9 . 5}$ & $\mathbf{1 2 1 5 . 7}$ & $\mathbf{7 3 . 3}$ & $\mathbf{8 5 0 . 5}$ & - \\
\hline $\begin{array}{l}\text { The Republic of } \\
\text { Dagestan }\end{array}$ & 2.9 & - & - & 2.9 & - \\
\hline $\begin{array}{l}\text { The Republic of } \\
\text { Ingushetia }\end{array}$ & - & - & - & - & - \\
\hline $\begin{array}{l}\text { Kabardino-Balkar } \\
\text { Republic }\end{array}$ & - & - & - & - & - \\
\hline $\begin{array}{l}\text { Karachay-Cherkess } \\
\text { Republic }\end{array}$ & 1.8 & 0.7 & 1.1 & - & - \\
\hline $\begin{array}{l}\text { Republic of North } \\
\text { Ossetia - Alania }\end{array}$ & 258.9 & - & 47.1 & 211.7 & - \\
\hline Chechen Republic & 716.2 & 683.4 & 0.5 & 32.4 & - \\
\hline Stavropol Territory & 1159.7 & 531.6 & 24.6 & 603.4 & - \\
\hline
\end{tabular}

The degree of investment attractiveness of industry and industrial enterprises in certain regions, the possibility of attracting the necessary funds for environmental protection activities, the production of environmentally friendly products can, in our opinion, be judged by the index of the volume of environmental costs.

The calculation of aggregated indices of the physical volume of environmental expenditures by sectors, types of expenditures and areas of environmental protection in Russia as a whole and the constituent entities of the Russian Federation is carried out on the basis of data on the volumes of environmental expenditures in actual and comparable prices. Figure 1 shows the index of the physical volume of environmental expenditures by constituent entities of the North Caucasian Federal District.

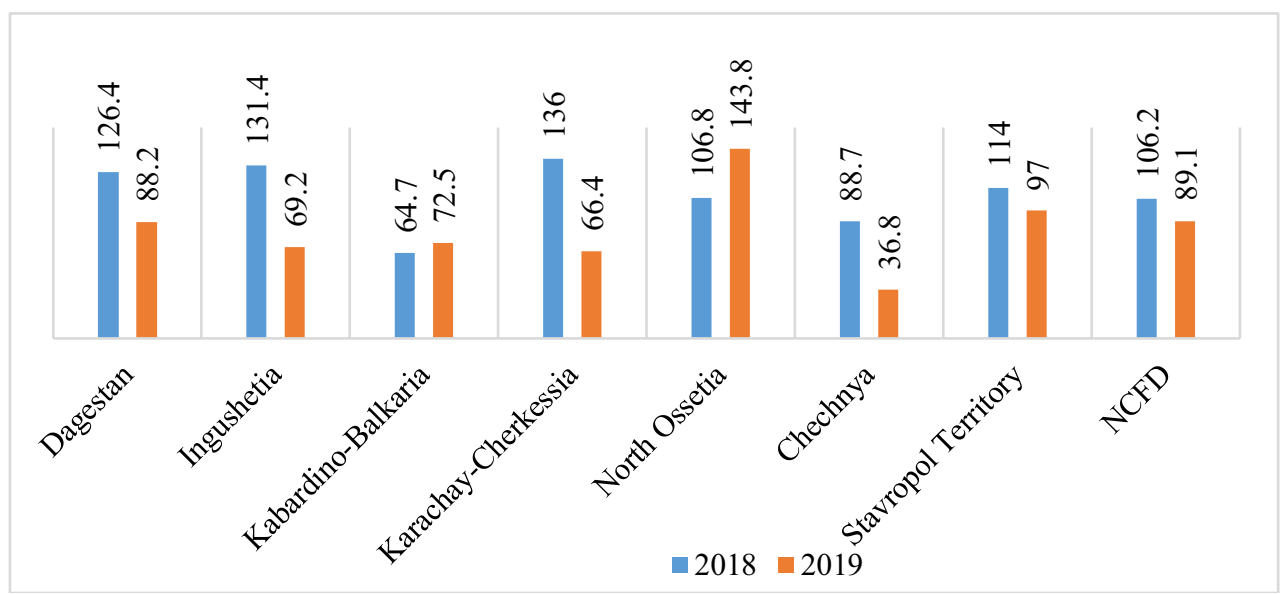

Fig. 1. Index of the physical volume of environmental expenditures (as a percentage of the previous year; in comparable prices). 
In 2019, the analysis of the current costs of environmental protection, according to the Federal State Statistics Service of the Russian Federation in the regional context of the republics and territories of the North Caucasus Federal District (Table 2) showed that the largest costs in the district were made for the collection and treatment of wastewater. The most acute problem for the North Caucasus is the collection and processing of solid waste. Funding for this area is extremely insufficient, as a result of underfunding, these are spontaneous waste dumps. In 2019, only 651 million rubles were allocated for waste management, and only 500 thousand rubles were received in the Republic of Ingushetia, 8 million rubles in Kabardino-Balkaria. The bulk of all funds were directed to the Stavropol Territory. If we consider this indicator per capita, then it turns out that 173 rubles were allocated for one resident of the Stavropol Territory, and 97 kopecks for one resident of the Republic of Ingushetia.

Table 2. Current expenditures for environmental protection in 2019 (million rubles).

\begin{tabular}{|l|c|c|c|c|c|c|}
\hline & Total & $\begin{array}{c}\text { of them on } \\
\text { air protection } \\
\text { and climate } \\
\text { change } \\
\text { prevention }\end{array}$ & $\begin{array}{c}\text { collectio } \\
\text { n and } \\
\text { treatme } \\
\text { nt of } \\
\text { waste } \\
\text { water }\end{array}$ & $\begin{array}{c}\text { protection } \\
\text { and } \\
\text { waste } \\
\text { managem } \\
\text { ent }\end{array}$ & $\begin{array}{c}\text { conservatio } \\
\text { n of } \\
\text { of land, } \\
\text { surface and } \\
\text { ground } \\
\text { waters }\end{array}$ & $\begin{array}{c}\text { biodiversity } \\
\text { and } \\
\text { protection } \\
\text { of natural } \\
\text { areas }\end{array}$ \\
\hline Russian Federation & 345464 & 61075 & 173688 & 79885 & 15347 & 514 \\
\hline $\begin{array}{l}\text { North Caucasian } \\
\text { Federal District }\end{array}$ & 3862 & 514 & 2564 & 651 & 54 & 3 \\
\hline $\begin{array}{l}\text { The Republic of } \\
\text { Dagestan }\end{array}$ & 130 & 30 & 28 & 18 & 15 & - \\
\hline $\begin{array}{l}\text { The Republic of } \\
\text { Ingushetia }\end{array}$ & 3 & - & 0,0 & 0,5 & 0.1 & - \\
\hline $\begin{array}{l}\text { Kabardino-Balkar } \\
\text { Republic }\end{array}$ & 186 & 46 & 118 & 8 & 13 & - \\
\hline $\begin{array}{l}\text { Karachay-Cherkess } \\
\text { Republic }\end{array}$ & 247 & 104 & 77 & 65 & 0.0 & 0.6 \\
\hline $\begin{array}{l}\text { Republic of North } \\
\text { Ossetia - Alania }\end{array}$ & 362 & 58 & 225 & 74 & 3 & - \\
\hline Chechen Republic & 11 & - & - & - & - & - \\
\hline Stavropol Territory & 2924 & 277 & 2116 & 485 & 24 & 3 \\
\hline
\end{tabular}

According to the Constitution of the Russian Federation (Article 76), which defines the subjects of joint jurisdiction, environmental protection and environmental safety are regulated by federal and regional mechanisms, which means the need to form a regional regulatory framework based on federal legislation and taking into account socio-economic conditions of the specific entity.

For example, in the Chechen Republic in 2006, the People's Assembly of Parliament adopted the Law "On Environmental Protection in the Chechen Republic", which regulates relations in the field of interaction between society and nature arising from the implementation of economic and other activities related to the impact on the natural environment as a major component environment within the territory of the Chechen Republic [7]. Similar documents were developed in other regions of the district. Also, in all the republics of the North Caucasus Federal District, programs have been developed that determine the strategic directions for the development of investment activities in the field of environmental protection. These programs are developed in accordance with Article 6 of the Federal Law and determine the jurisdiction of the constituent entities of the Russian Federation, which includes the determination of the main directions of environmental 
protection in the territories of these constituent entities, taking into account the geographical, natural, socio-economic and other characteristics of the region.

The main directions of the programs reflect the positions of the investment strategy in the field of environmental protection and make it possible to develop strategic programs for the development of industry based on the introduction of modern environmentally friendly technologies for the production of products and the processing of the resulting waste. The implementation of top-priority plans aimed at achieving the program goals of the regional environmental and investment policies will, in our opinion, allow the population to realize the right to a healthy environment, ensure environmental safety, improve the quality of atmospheric air, reduce the intake of pollutants with wastewater in the water area based on the implementation of eco-efficient investment projects [10-14].

The implementation of targeted programs and plans is based on improving the mechanisms of state regulation, which should lead to an increase in resource-saving and environmental motivations when making industrial, socio-economic, urban planning and other decisions, which ultimately is aimed at ensuring the necessary guarantees for the protection and implementation of the constitutional rights of residents of the region for a healthy and favorable environment, and, consequently, an improvement in the quality of life.

The main regulatory legal acts governing investment activities in the field of environmental protection and the use of natural resources will be divided into two groups. The first includes acts allowing the construction of new facilities, the introduction of new or modernized technologies for the more rational, economical use of natural resources, including subsoil, land and surface waters. In the second group we will include acts on ensuring the environmental safety of the population, regulating general issues of radiation and chemical safety, protection of atmospheric air, surface waters, soils, green spaces and specially protected natural areas. The third group includes normative legal acts on the regulation of investment activities in order to protect the environment from production and consumption waste - solid household, toxic and biological waste.

\section{Conclusions}

Thus, investment projects for the use of waste in the form of secondary resources fall under both groups of regulatory legal acts, since, firstly, they reduce the volume of use of primary resources, and, secondly, they reduce the dumping of the territory, contributing to a more rational use of land resources.

Thus, the main regulatory framework of the municipal mechanism of control and regulation is created at the federal and regional levels of government, and the municipal management systems themselves exercise only direct control and do not participate in the creation of mechanisms of legal and economic regulation, including investment activities of ecological orientation.

In our opinion, the electronic model of the territorial scheme in the field of waste management, including solid municipal waste, developed by INNOBALT LLC specialists in 2019, can contribute to the determination of the main principles, goals, directions and tasks of the mechanism of state regulation of investment activities in the Chechen Republic. The main purpose of the scheme is the transition to complete industrial processing of all generated waste. In this model, an analysis is presented that contains the justification for the creation of production facilities for the processing of solid household waste, the calculation of the required capacity of existing processing complexes, enterprises, and the determination of the basic conditions for the placement of newly constructed ones.

Thus, the model provides for specific measures both to create a regulatory and legal mechanism for state regulation of investment activities, and an economic one, including 
methods of accelerated depreciation of fixed assets in order to reduce the payback period of investment projects.

\section{References}

1. N.A. Nefedov, Taxation in Russia: a handbook for managers and entrepreneurs (M., Finance and statistics, 2004)

2. E.R. Shaibakova, Balanced development of industrial and economic complexes (Ufa, Publishing house of BashSU, 2004)

3. Guidelines for the phased implementation of an environmental management system using environmental performance assessment. GOST $R$ ISO 14005-2013, https://docs.cntd.ru/document/1200108766

4. V.N. Lopatin, NIA-Priroda 10, 25-32 (2000)

5. T.S. Kolmykova, Yu.N. Prikhodko, E.O. Astapenko, Region: systems, economics, management 3(46) (2019)

6. S.N. Gudyrin, State regulation of regional development (Astrakhan, Publishing house of ASU, 2003)

7. E. Karieva, L. Akhmetshina, A. Mottaeva, E3S Web of Conferences 217, 07008 (2020) https://doi.org/10.1051/e3sconf/202021707008

8. S.A. Makhosheva, Izvestiya Kabardino-Balkar Scientific Center of the Russian Academy of Sciences 60(4) (2018)

9. S.A. Makhosheva, Z.Sh. Ivanova, Izvestiya of Kabardino-Balkarian Scientific Center of the Russian Academy of Sciences 61(5) (2018)

10. S. Tumenova, M. Kandrokova, S. Makhosheva et al., Revista Espacios 39(26), 12 (2018)

11. A. Gurtuev, E. Derkach, S. Makhosheva, Z. Ivanov, Heliyon 6, 11 (2020)

12. S. Makhosheva, N. Rud, M. Kandrokova, M. Israilov, F. Shinahova, Revista Espacios 9(47) (2018)

13. S. Niyazbekova, B. Jazykbayeva, A. Mottaeva, E. Beloussova, B. Suleimenova, A. Zueva, E3S Web of Conferences 244, $10058 \quad$ (2021) https://doi.org/10.1051/e3sconf/202124410058

14. S. Barykin, E. Smirnova, P.Sharapaev, A. Mottaeva, Academy of Strategic Management Journal 20(2) (2021) 